DOI: $10.19195 / 0137-1134.106 .18$

\title{
JOANNA BRZEZIŃSKA
}

Uniwersytet Wrocławski

JAN GOLA

Uniwersytet Ekonomiczny we Wrocławiu

\section{UWAGI O OBOWIĄZKACH PRZEDSIĘBIORCY TELEKOMUNIKACYJNEGO W STANACH NADZWYCZAJNYCH}

\section{WSTĘP}

Wystąpienie stanu nadzwyczajnego może obligować podmioty prowadzące działalność gospodarczą do spełnienia wielu obowiązków. Co ważne, mogą one dotyczyć wielu sfer aktywności finansowej i w praktyce powodować pewne wątpliwości interpretacyjne. Zakres zastosowania stanów nadzwyczajnych wynika z charakteru instytucji jurydycznych. Mogą one być umiejscowione w wielu gałęziach prawnych - między innymi w sferze prawa administracyjnego oraz prawa karnego. Cechują się one występowaniem wielu zakazów, nakazów, dozwoleń. Nie ulega wątpliwości, że wskazane środki mogą być prewencyjne i związane są z metodą działania administracji, którą określa się jako styl rozwiązywania spraw określonego typu. Obecnie zaś obserwuje się swoistą politykę form działania i zachowania proporcji elementów przymusu i przekonywania ${ }^{1}$.

W artykule zostaną przedstawione najważniejsze obowiązki, jakie ustawodawca skierował do przedsiębiorców telekomunikacyjnych, którzy w społecznej gospodarce rynkowej zajmują coraz bardziej znaczącą pozycję. Już w tym miejscu warto zwrócić uwagę, że sama koncepcja społecznej gospodarki rynkowej odrzuca tradycyjny, liberalny dualizm między państwem a gospodarką. Jednocześnie koncepcji tej obcy jest również obraz państwa jako jedynego (całkowitego) suwerena w obszarze gospodarki, który w sposób centralny planuje i zarządza (kieruje) wszystkimi procesami gospodarczymi².

\footnotetext{
${ }^{1}$ Zob. J. Starościak, Administracja. Zagadnienia teorii i praktyki, Warszawa 1974, s. 83.

2 M. Szydło, Swoboda działalności gospodarczej, Warszawa 2005, s. 5.
} 


\section{PRZEDSIĘBIORCA TELEKOMUNIKACYJNY — UWAGI OGÓLNE}

Na początku artykułu warto wyjaśnić podstawowe kwestie związane z tytułowym zagadnieniem. Najważniejszym aktem prawnym, na którym zostanie skupiona uwaga, jest ustawa z dnia 16 lipca 2004 r. - Prawo telekomunikacyj$\mathrm{ne}^{3}$. Normodawca stwierdził w niej, że przez przedsiębiorcę telekomunikacyjnego rozumie się podmiot uprawniony do wykonywania działalności gospodarczej na podstawie odrębnych przepisów, który wykonuje działalność gospodarczą polegającą na dostarczaniu sieci telekomunikacyjnych, świadczeniu usług towarzyszących lub świadczeniu usług telekomunikacyjnych, przy czym przedsiębiorca telekomunikacyjny uprawniony do świadczenia usług telekomunikacyjnych zwany jest „dostawcą usług”, a przedsiębiorca, który dostarcza publiczne sieci telekomunikacyjne lub udogodnienia towarzyszące, zwany jest „operatorem”.

Głównym warunkiem otrzymania statusu przedsiębiorcy telekomunikacyjnego jest uzyskanie uprawnień do wykonywania działalności gospodarczej ${ }^{4}$. Warto wskazać, że definicja przedsiębiorcy znajduje się między innymi w ustawie z dnia 2 lipca 2004 r. o swobodzie działalności gospodarczej ${ }^{5}$. Zgodnie z tym aktem prawnym przedsiębiorcą jest osoba fizyczna, osoba prawna i jednostka organizacyjna niebędąca osobą prawną, której odrębna ustawa przyznaje zdolność prawną - wykonująca we własnym imieniu działalność gospodarczą ${ }^{6} . \mathrm{Za}$ przedsiębiorców uznaje się także wspólników spółki cywilnej w zakresie wykonywanej przez nich działalności gospodarczej ${ }^{7}$. Należy pamiętać, że ze względu na to, iż działalność telekomunikacyjna jest działalnością regulowaną, kolejnym wymogiem do jej prowadzenia jest uzyskanie uprawnień sektorowych poprzez

3 Dz.U. z 2014 r., poz. 243 z późn. zm. (dalej: PT).

4 Zob. T. Kocowski, Przedsiębiorcy, [w:] A. Borkowski et al., Administracyjne prawo gospodarcze, Wrocław 2009, s. 165.

${ }^{5}$ Dz.U. z 2015 r., poz. 584 z późn. zm. (dalej: u.s.d.g.).

${ }^{6}$ Jeżeli dochodzi do podjęcia działalności gospodarczej zakazanej przez przepisy prawa, to nie tylko nie korzysta ona z ochrony prawnej, ale jest również udaremniana i sankcjonowana środkami przewidzianymi w przepisach na przykład prawa karnego, prawa finansowego. Decydujące znaczenie dla dopuszczalności prawnej działalności gospodarczej ma więc brak ustawowego zakazu prowadzenia działalności gospodarczej bądź też ustawowego zastrzeżenia określonej działalności gospodarczej na rzecz państwa lub też innego podmiotu publicznoprawnego. Konieczną więc przesłanką uznania działalności za gospodarczą jest jej zgodność z obowiązującym porządkiem prawnym. S. Biernat, A. Wasilewski, Ustawa o działalności gospodarczej, Kraków 1997, s. 14; K. Strzyczkowski, Prawo gospodarcze publiczne, Warszawa 2011, s. 223.

7 Art. 4 u.s.d.g. Naczelny Sąd Administracyjny wskazał, że działalność gospodarcza to „prawnie określona sytuacja, którą trzeba oceniać na podstawie zbadania konkretnych okoliczności faktycznych, wypełniających lub nie wypełniających znamiona tejże działalności”. Zob. wyrok Naczelnego Sądu Administracyjnego z dnia 2 grudnia 1994 r., SA/Łd 741/94. Zob. T. Szanciło, Formy prowadzenia działalności gospodarczej w Polsce przez podmioty zagraniczne, Warszawa 2006, s. 173 n. 
dokonanie wpisu ${ }^{8}$ do rejestru przedsiębiorców telekomunikacyjnych ${ }^{9}$. Działalnością regulowaną ${ }^{10}$ zgodnie $\mathrm{z}$ ustawą o swobodzie działalności gospodarczej jest działalność gospodarcza, której wykonywanie wymaga spełnienia szczególnych warunków, określonych przepisami prawa ${ }^{11}$. Organem, który prowadzi rejestr, jest Prezes Urzędu Komunikacji Elektronicznej ${ }^{12}$. Co ważne, przedsiębiorca wykreślony z rejestru z powodu wydania decyzji o zakazie wykonywania działalności gospodarczej, a także przedsiębiorca, który wykonywał działalność gospodarczą bez wpisu do rejestru do działalności gospodarczej regulowanej, może uzyskać ponownie wpis do rejestru nie wcześniej niż po upływie trzech lat od dnia wydania decyzji o wykreśleniu z rejestru działalności regulowanej (art. 72 u.s.d.g.).

\section{STANY NADZWYCZAJNE — UJĘCIE OGÓLNE}

Nie ulega wątpliwości, że istotnym zagadnieniem będzie również krótka charakterystyka stanów nadzwyczajnych, które mogą być wprowadzone w Polsce $^{13}$. Ustrojodawca wyszczególnił je w Konstytucji RP z dnia 2 kwietnia 1997 r. ${ }^{14}$ W sytuacjach szczególnych zagrożeń, jeżeli zwykłe środki konstytucyjne są niewystarczające ${ }^{15}$, może zostać wprowadzony odpowiedni stan nadzwyczajny: stan

${ }^{8}$ Zob. M. Strzelbicki, Wpis do rejestru działalności regulowanej, „Ruch Prawniczy, Ekonomiczny i Społeczny" 2005, nr 4, s. 67.

9 Zob. M. Szydło, op. cit., s. 281.

10 Zob. M. Etel, Regulowana działalność gospodarcza a zasada wolności gospodarczej, „Państwo i Prawo" 2007, z. 2, s. 41.

11 Art. 5 pkt 5 u.s.d.g. R. Sowiński zauważa, że z określenia tego nie wynika wiele. Według autora pojęcie jest bardzo lakoniczne, wiadomo tylko, że mamy w tym przypadku pewna formę reglamentacji działalności gospodarczej. Ogólnikowość tego przepisu pozwala na objęcie reglamentowaniem każdej działalności gospodarczej, jeżeli tylko ustawodawca uzna, że jej charakter wymaga spełnienia przez wykonującego szczególnych warunków. Nie wskazano, o jakiego rodzaju warunki może chodzić, mogą więc one być związane z przedmiotem działalności, podmiotami, które je wykonują, wyposażeniem technicznym niezbędnym do realizacji zadań gospodarczych, a nawet czasu i miejsca wykonywania działalności. Ponadto nie dla wszystkich rodzajów działalności gospodarczej ustalone zostały szczegółowe warunki dokonywania wpisów do rejestrów tych działalności. Stopniowo jednak poszczególni ministrowie wydają rozporządzenia w tej sprawie. Zob. R. Sowiński, Rejestry i ewidencje działalności gospodarczej i przedsiębiorców, Wrocław 2007 s. 256. Zob. też idem, Administracyjna reglamentacja działalności gospodarczej, Wrocław 2006, s. 322.

12 Dalej: Prezes UKE.

13 Zob. B. Opaliński, Stan wojenny we współczesnym polskim porządku prawnym, „Przegląd Prawa Handlowego" 2011, nr 7-8, s. 65.

14 Art. 228 Konstytucji Rzeczypospolitej Polskiej z dnia 2 kwietnia 1997 r., Dz.U. z 1997 r. Nr 78, poz. 483 z późn. zm.

15 Zob. postanowienie Trybunału Konstytucyjnego z dnia 6 marca 2001 r., S 1/01. 
wojenny ${ }^{16}$, stan wyjątkowy ${ }^{17}$ lub stan klęski żywiołowej ${ }^{18}$. Ponadto warto zaznaczyć, że stan nadzwyczajny może być wprowadzony tylko na podstawie ustawy, w drodze rozporządzenia, które podlega dodatkowemu podaniu do publicznej wiadomości ${ }^{19}$. Co ważne, działania podjęte w wyniku wprowadzenia stanu nadzwyczajnego muszą odpowiadać stopniowi zagrożenia i powinny zmierzać do jak najszybszego przywrócenia normalnego funkcjonowania państwa ${ }^{20}$.

Interesujący może być pogląd, zgodnie z którym

należałoby przede wszystkim dokonać rozróżnienia między stanem nadzwyczajnym, jako pewnym typem idealnym, a stanami nadzwyczajnymi, jako konkretnymi rozwiązaniami prawnymi w zakresie sprostania przez państwo sytuacjom nadzwyczajnym [...]. Ze stanem nadzwyczajnym będziemy mieli do czynienia wówczas, gdy państwo nie tylko nie byłoby w stanie poradzić sobie z sytuacją kryzysową środkami pozostającymi na co dzień w jego dyspozycji, ale ponadto działania aparatu państwa musiałyby opierać się na obowiązującym prawie, chociaż należy pamiętać, iż sam akt proklamacji stanu nadzwyczajnego, z natury rzeczy mający charakter polityczny, nie podlega sądowej kontroli21.

\section{OBOWIĄZKI PRZEDSIĘBIORCY TELEKOMUNIKACYJNEGO}

W stanach nadzwyczajnych ustawodawca przewiduje szczególne rodzaje obowiązków skierowanych do przedsiębiorców telekomunikacyjnych (zob. dział VIII PT) ${ }^{22}$. Zgodnie z PT przedsiębiorca telekomunikacyjny jest obowiązany do wykonywania zadań i obowiązków na rzecz obronności, bezpieczeństwa państwa oraz bezpieczeństwa i porządku publicznego ${ }^{23}$. Istotne jest, że ustawodawca wskazuje, że kto nie wypełnia lub nienależycie wypełnia obowiązki lub zadania na rzecz obronności i bezpieczeństwa państwa oraz bezpieczeństwa i porządku publicznego, w zakresie i na warunkach określonych w ustawie lub decy-

16 Zob. ustawa z dnia 29 sierpnia 2002 r. o stanie wojennym oraz o kompetencjach Naczelnego Dowódcy Sił Zbrojnych i zasadach jego podległości konstytucyjnym organom Rzeczypospolitej Polskiej, Dz.U. z 2016 r., poz. 851.

17 Zob. ustawa z dnia 21 czerwca 2002 o stanie wyjątkowym, Dz.U. z 2016 r., poz. 886.

18 Zob. ustawa z dnia 18 kwietnia 2002 r. o stanie klęski żywiołowej, Dz.U. z 2014 r., poz. 333 z późn. zm.

19 Zob. wyrok Naczelnego Sądu Administracyjnego z dnia 10 stycznia 2002 r., I SA/Kr 2180/01.

20 Więcej na temat stanów nadzwyczajnych: M. Brzeziński, Stany nadzwyczajne w polskich konstytucjach, Warszawa 2007, s. 11 n.; G. Krawiec, Stany nadzwyczajne i zarzadzanie kryzysowe a uprawnienia organów administracji publicznej, [w:] Bezpieczeństwo - powinność czy gwarancja?, t. 2. Stany nadzwyczajne a szczególne zagrożenia państwa, red. T. Miłkowski, Sosnowiec 2015, s. 25 n.

21 L. Mażewski, Kilka uwag o instytucji stanu nadzwyczajnego, „Wojskowy Przegląd Prawniczy" 2009, nr 2, s. 36.

22 Por. http://www.sea.org.pl/?q=pl/node/891 (dostęp: 1 lipca 2016).

23 Zob. M. Rogalski, Obowiązki na rzecz obronności, bezpieczeństwa państwa oraz bezpieczeństwa i porządku publicznego, [w:] Prawo telekomunikacyjne, red. M. Rogalski, Warszawa 2011, s. $682 \mathrm{n}$. 
zjach wydanych na jej podstawie, podlega karze pieniężnej (zob. art. 209 ust. 1 pkt 10 PT). Karę pieniężną nakłada Prezes UKE, w drodze decyzji, w wysokości do $3 \%$ przychodu ukaranego podmiotu, osiągniętego w poprzednim roku kalendarzowym. Ustalając wysokość kary pieniężnej, Prezes UKE uwzględnia zakres naruszenia, dotychczasową działalność podmiotu oraz jego możliwości finansowe (zob. art. 210 ust. 2 PT).

Przedsiębiorca telekomunikacyjny, w celu zapewnienia ciągłości świadczenia usług telekomunikacyjnych lub dostarczania sieci telekomunikacyjnej, jest obowiązany uwzględniać możliwość wystąpienia: sytuacji kryzysowych, stanów nadzwyczajnych, bezpośrednich zagrożeń dla infrastruktury przedsiębiorcy. Normodawca wskazuje, że są to „sytuacje szczególnych zagrożeń" (art. 176 a PT). Bardzo istotny jest fakt, że przedsiębiorca zobowiązany jest mieć aktualne i uzgodnione plany działań ${ }^{24} \mathrm{~W}$ sytuacjach wystąpienia owych zagrożeń, dotyczące m.in: współpracy z innymi przedsiębiorcami telekomunikacyjnymi; współpracy z zagranicznymi operatorami telekomunikacyjnymi, a w szczególności państw sąsiadujących; współpracy z podmiotami i służbami wykonującymi zadania w zakresie ratownictwa, niesienia pomocy ludności, a także zadania na rzecz obronności, bezpieczeństwa państwa oraz bezpieczeństwa i porządku publicznego oraz z podmiotami właściwymi w sprawach zarządzania kryzysowego; zabezpieczenia infrastruktury telekomunikacyjnej w sytuacjach szczególnych zagrożeń oraz przed nieuprawnionym dostępem ${ }^{25}$.

Należy wskazać, że przedsiębiorca telekomunikacyjny powinien przystąpić do realizacji planu niezwłocznie w przypadku stwierdzenia wystąpienia sytuacji szczególnego zagrożenia lub po uzyskaniu informacji o wystąpieniu takiej sytuacji od podmiotów lub służb państwowych z zakresu ratownictwa, obronności, porządku publicznego lub zarządzania kryzysowego ${ }^{26}$. Decyzje o podjęciu wykonania planu podejmuje przedsiębiorca telekomunikacyjny, a uwarunkowane jest to oceną sytuacji i stopniem natężenia zagrożeń z nią związanych ${ }^{27}$. Należy zgodzić się z S. Piątkiem, który zauważa, że

${ }^{24}$ Zob. rozporządzenie Rady Ministrów z dnia 4 stycznia 2010 r. w sprawie planu działań przedsiębiorcy telekomunikacyjnego w sytuacjach szczególnych zagrożeń, Dz.U. z 2010 r. Nr 15, poz. 77. Zgodnie z $\S 4$ tego aktu prawnego przedsiębiorca sporządzający plan dokonuje: analizy potencjalnych, szczególnych zagrożeń na obszarze, na którym wykonuje działalność telekomunikacyjną; oceny wpływu szczególnych zagrożeń na własną infrastrukturę telekomunikacyjną oraz zdolność do zachowania ciągłości prowadzonej przez siebie działalności telekomunikacyjnej; analizy potrzeb w zakresie świadczenia, utrzymania i odtwarzania usług telekomunikacyjnych oraz dostępu telekomunikacyjnego. Istotny jest także fakt, że normodawca wyróżnił trzy rodzaje planów: ogólny, rejonowy i lokalny. Przedsiębiorca telekomunikacyjny sporządza plan działań dla faktycznego obszaru, na którym wykonuje swoją działalność.

25 Zob. S. Piątek, Prawo telekomunikacyjne. Komentarz, Warszawa 2013, s. 1052 n.

26 Zob. Wytyczne do sporządzenia planów działań przedsiębiorców telekomunikacyjnych w sytuacjach szczególnych zagrożeń, https://www.uke.gov.pl/files/?id_plik=6820 (dostęp: 1 lipca 2016).

27 S. Piątek, op. cit., s. 1055. 
ze względów praktycznych należy dążyć do skoordynowanego podjęcia takiej decyzji przez wszystkich przedsiębiorców, którzy prowadzą działalność na obszarach objętych zagrożeniem i dysponują odpowiednimi sieciami lub urządzeniami ${ }^{28}$.

Kolejnym bardzo ważnym obowiązkiem, na który należy zwrócić uwagę, jest udostępnianie urządzeń telekomunikacyjnych niezbędnych do przeprowadzenia akcji ratowniczej innemu przedsiębiorcy telekomunikacyjnemu, zagranicznym operatorom telekomunikacyjnym, a w szczególności państwom sąsiadującym (art. 177 ust. 3 PT). Obowiązek ten powstaje w przypadku wystąpienia sytuacji szczególnego zagrożenia. Normodawca stwierdza, że urządzenia telekomunikacyjne są udostępniane nieodpłatnie. Przy udostępnianiu tych urządzeń powinna być zachowana zasada minimalizowania negatywnych skutków takiego udostępnienia dla ciągłości wykonywania działalności telekomunikacyjnej przez przedsiębiorcę29.

Warto wskazać także, że podmiotami uprawnionymi do korzystania z przedmiotowych urządzeń są podmioty koordynujące działania ratownicze, podmioty właściwe w sprawach zarządzania kryzysowego, służby alarmowe oraz podmioty realizujące zadania w zakresie obronności, bezpieczeństwa i porządku publicznego ${ }^{30}$.

Ustawodawca wskazuje, że w sytuacji wystąpienia szczególnego zagrożenia Prezes UKE może, w drodze decyzji, nałożyć na przedsiębiorców telekomunikacyjnych obowiązki dotyczące: utrzymania ciągłości lub odtwarzania, dostarczania sieci telekomunikacyjnej, świadczenia usług telekomunikacyjnych; ograniczenia niektórych publicznie dostępnych usług telekomunikacyjnych; ograniczenia zakresu lub obszaru eksploatacji sieci telekomunikacyjnych i urządzeń telekomunikacyjnych, używania urządzeń radiowych; nakazu nieodpłatnego świadczenia, w określonym zakresie, publicznie dostępnych usług telefonicznych z aparatów publicznych. Powinien kierować się on rozmiarem zagrożenia i potrzebą ograniczenia jego skutków, z zachowaniem zasady minimalizowania negatywnych skutków nałożonych obowiązków dla ciągłości świadczenia usług i dla działalności gospodarczej przedsiębiorcy telekomunikacyjnego. Warto dodać, że decyzji nadaje się rygor natychmiastowej wykonalności (art. $178 \mathrm{PT})^{31}$.

Należy jednak pamiętać, że

Prezes UKE, nakładając na przedsiębiorców telekomunikacyjnych obowiązki w sytuacji szczególnego zagrożenia, powinien kierować się rozmiarem zagrożenia i potrzebą ograniczenia jego skutków. Powinien także przestrzegać zasady minimalizowania negatywnych skutków nałożonych

28 Ibidem.

29 M. Rogalski, Komentarz do art. 177, [w:] Prawo telekomunikacyjne. Komentarz, red. M. Rogalski, Warszawa 2010, s. 904-905.

30 S. Piątek, op. cit., s. 1058.

31 Zob. na temat wykonalności aktów administracyjnych A. Krawczyk, Wykonalność aktu i czynności organu administracji publicznej, Warszawa 2013, passim. 
obowiązków dla ciągłości świadczenia usług i dla działalności gospodarczej przedsiębiorcy telekomunikacyjnego ${ }^{32}$.

Istotny jest także obowiązek przedsiębiorcy telekomunikacyjnego wykonywania zadań i obowiązków w zakresie przygotowania i utrzymywania wskazanych elementów sieci telekomunikacyjnych w celu zapewnienia telekomunikacji na potrzeby systemu kierowania bezpieczeństwem narodowym, w tym obroną państwa, realizowanych na zasadach określonych w planach, decyzjach lub umowach zawartych między przedsiębiorcami telekomunikacyjnymi a uprawnionymi podmiotami.

Przedsiębiorca telekomunikacyjny jest obowiązany między innymi do: zapewnienia warunków technicznych i organizacyjnych dostępu i utrwalania, umożliwiających jednoczesne i wzajemnie niezależne uzyskiwanie przez Policję, Straż Graniczną, Agencję Bezpieczeństwa Wewnętrznego, Służbę Kontrwywiadu Wojskowego, Żandarmerię Wojskową, Centralne Biuro Antykorupcyjne i wywiad skarbowy dostępu do: przekazów telekomunikacyjnych nadawanych lub odbieranych przez użytkownika końcowego lub telekomunikacyjne urządzenie końcowe, posiadanych przez przedsiębiorcę danych związanych z przekazami telekomunikacyjnymi oraz uzyskiwanie przez uprawnione podmioty danych związanych ze świadczoną usługą telekomunikacyjną. Jest on obowiązany także do utrwalania na rzecz sądu i prokuratora przekazów telekomunikacyjnych (art. 179 PT) ${ }^{33}$.

Przedsiębiorca telekomunikacyjny jest obowiązany do wskazania Prezesowi UKE jednostki organizacyjnej lub osoby mającej siedzibę lub miejsce zamieszkania na terytorium Rzeczypospolitej Polskiej uprawnionej do reprezentowania tego przedsiębiorcy w sprawach związanych z zapewnieniem warunków dostępu i utrwalania; przedsiębiorcy telekomunikacyjnego, który będzie w jego imieniu wykonywał określone przez ustawodawcę obowiązki; przedsiębiorcy telekomunikacyjnego, wspólnie z którym będzie zapewniał warunki dostępu i utrwalania za pomocą tych samych interfejsów (art. 179 ust. 8 PT).

W kontekście realizacji omawianych obowiązków ciekawy jest wyrok Sądu Najwyższego, w którym zostało stwierdzone, że

konieczność przeznaczenia środków na zakup urządzeń i oprogramowania, konieczność zbudowania systemu do „legalnego podsłuchu” oraz konieczność zatrudnienia w tym celu pracowników - to nie są trudności finansowe, techniczne czy organizacyjne, uniemożliwiające przedsiębiorcy telekomunikacyjnemu wykonanie zadań i obowiązków na rzecz obronności, bezpieczeństwa państwa oraz bezpieczeństwa i porządku publicznego ${ }^{34}$.

32 M. Rogalski, Komentarz do art. 178, [w:] Prawo telekomunikacyjne. Komentarz, red. M. Rogalski, s. 904-905.

33 Zob. wyrok Wojewódzkiego Sądu Administracyjnego w Warszawie z dnia 4 stycznia 2009 r., VI SA/Wa 2140/08.

34 Wyrok Naczelnego Sądu Administracyjnego w Warszawie z dnia 11 lutego 2011 r., II GSK $241 / 10$. 
Sąd stwierdził, iż:

zgodzić należy się z tym, że [...] w sposób oczywisty wykonywanie tych ustawowych zadań i obowiązków wiąże się z kwestiami organizacyjnymi i technicznymi, koniecznością i poniesieniem z tego tytułu kosztów. Nie są to jednak — automatycznie — trudności uniemożliwiające wykonanie zadań $^{35}$

Niewątpliwie należy także wskazać na obowiązek blokowania połączeń telekomunikacyjnych lub przekazów informacji. W praktyce będzie on dotyczyć przedsiębiorców telekomunikacyjnych będących operatorami, gdyż tylko oni będą mogli faktycznie zrealizować ten obowiązek, jako posiadający sieć telekomunikacyjną. Ponadto trzeba pamiętać, że przedmiotowy obowiązek dotyczy wszystkich sieci telekomunikacyjnych. Powinien on być realizowany niezwłocznie. Po wykonaniu obowiązku można dopiero podejmować czynności prawne zmierzające do podważenia tego żądania, a przedsiębiorca nie może domagać się odszkodowania w następstwie przerwania świadczenia usług telekomunikacyjnych, chyba że żądanie było sprzeczne z prawem i zostało to stwierdzone prawomocnym wyrokiem $(\text { art. } 180 \mathrm{PT})^{36}$.

Z punktu widzenia tematu ciekawy może być również obowiązek zapewnienia warunków dostępu i utrwalania oraz udostępniania uprawnionym podmiotom danych przez przedsiębiorców telekomunikacyjnych (art. 180d PT). Normy dotyczące tej sfery mogą odgrywać ważną rolę w przypadku wystąpienia stanu nadzwyczajnego ${ }^{37}$. Podmioty prowadzące działalność telekomunikacyjną obowiązane są wydać sądowi lub prokuratorowi, na żądanie zawarte w postanowieniu, dane wskazane w ustawie, jeżeli mają one znaczenie dla toczącego się postępowania (art. $218 \S 1$ k.p.k.) $)^{38}$. Warto pamiętać, że tylko sąd lub prokurator mają prawo otwierać lub zarządzić otwarcie wykazów zawierających takie dane ${ }^{39}$.

Warto także wspomnieć o orzeczeniu Sądu Najwyższego, które dotyczyło wspomnianego obowiązku. Sąd stwierdził, że „przepis art. 180d ustawy z dnia 16 lipca 2004 r. - Prawo telekomunikacyjne (Dz.U. z 2014 r., poz. 243) ma zastosowanie do danych związanych z usługą przekazywania poczty elektronicznej przez przedsiębiorców telekomunikacyjnych. Nie ma natomiast zastosowania do udzielania przez usługodawcę organom państwa na potrzeby prowadzonych przez nie postępowań danych w zakresie określonym art. 18 ust. 6 ustawy z dnia 18 lip-

35 Ibidem.

${ }^{36}$ M. Rogalski, Komentarz do art. 178, s. 948.

37 Zob. wyrok Trybunału Konstytucyjnego z dnia 30 lipca 2014 r., K 23/11; postanowienia Sądu Apelacyjnego w Białymstoku z dnia 6 kwietnia 2011 r., I ACz 279/11.

38 Ustawa z dnia 6 czerwca 1997 r. — Kodeks postępowania karnego, Dz.U. z 1997 r. Nr 89, poz. 555 z późn zm.

39 Więcej M. Kiziński, Retencja danych telekomunikacyjnych, „Prokuratura i Prawo” 2016, nr 1 , s. $138 \mathrm{n}$. 
ca 2002 r. o świadczeniu usług drogą elektroniczną (Dz.U. z 2013 r., poz. 1422), a dotyczących samej usługi świadczonej drogą elektroniczną"40.

Przedsiębiorca telekomunikacyjny jest również obowiązany dostarczać Prezesowi UKE danych dotyczących infrastruktury telekomunikacyjnej eksploatowanej lub używanej przez tego przedsiębiorcę, niezbędnej do przygotowania systemów łączności na potrzeby obronne państwa, w tym systemu kierowania bezpieczeństwem narodowym, i aktualizować niezwłocznie po każdej zmianie (art. 180f).

Wskazana norma powiązana jest także z ustawą z dnia 23 sierpnia $2001 \mathrm{r}$. o organizowaniu zadań na rzecz obronności państwa realizowanych przez przedsiębiorcó $\mathrm{w}^{41}$. Warto wskazać, że ustawodawca $\mathrm{w}$ tym akcie prawnym nakłada administracyjny obowiązek spoczywający na przedsiębiorcy telekomunikacyjnym wykonywania zadań w zakresie przygotowania i utrzymania infrastruktury telekomunikacyjnej dla systemów łączności na potrzeby obronne państwa ${ }^{42}$. Zgodnie $\mathrm{z}$ art. 7 ustawy zadania na rzecz obronności państwa nakładane są na przedsiębiorcę w drodze decyzji administracyjnej wydanej przez odpowiedni organ ${ }^{43}$.

\section{PODSUMOWANIE}

W przypadku wprowadzenia stanu nadzwyczajnego bardzo ważną rolę mogą odgrywać obowiązki prawne skierowane do przedsiębiorców telekomunikacyjnych. Mnogość zakazów i nakazów określonego działania w praktyce może budzić pewne wątpliwości. Co istotne, w przypadku tytułowych obowiązków będą miały zastosowanie instytucje wielu dziedzin prawa.

W dobie powszechnego zagrożenia terrorystycznego to właśnie instrumenty prawne skierowane do przedsiębiorców telekomunikacyjnych mogą odgrywać istotną rolę prewencyjną oraz zachowawczą. Odpowiednie służby we współpracy z przedsiębiorcami telekomunikacyjnymi mogą doprowadzić do zapobiegania wielu tragediom oraz w sposób bardziej skuteczny dbać o bezpieczeństwo państwa. Pojawia się jednak wątpliwość, czy katalog uprawnień przysługujących obecnie przedsiębiorcom w wyjątkowych okolicznościach może w istocie skutecznie przeciwdziałać licznym niebezpieczeństwom, jakie mogą pojawiać się i występować w przestrzeni publicznej, oraz czy nie należałoby dokonać jego rozszerzenia, celem wzmocnienia i poprawy stanu bezpieczeństwa państwa oraz jego obywateli.

40 Zob. uchwała Sądu Najwyższego z dnia 30 września 2014 r., I KZP 18/14.

41 Dz.U. z 1997 r. Nr 122, poz. 1320 z późn. zm.

42 M. Rogalski, Obowiązki na rzecz obronności, bezpieczeństwa państwa oraz bezpieczeństwa i porzadku publicznego, s. 725.

${ }^{43}$ Może nim być na przykład minister wykonujący prawa z tytułu posiadania akcji lub udziałów należących do skarbu państwa, w uzgodnieniu z ministrem właściwym ze względu na przedmiot działania spółki, a także wojewoda. 
Wydawać się może, że w związku z tym konieczna jest również akceptacja społeczna wielu działań wykonywanych przez przedsiębiorców telekomunikacyjnych, którzy często zobligowani pozostają do wielu aktywności niekorzystnych z punktu widzenia finansów przedsiębiorstwa.

\section{REMARKS ON THE DUTIES OF A TELECOMMUNICATION PROVIDER DURING EXTRAORDINARY MEASURES}

\section{Summary}

The occurrence of extraordinary measures may oblige businesses to perform many duties. Importantly, they can address many spheres of financial activity and, in practice, cause some interpretation doubts. The scope of utilization of extraordinary measures results from the nature of juridical institutions. In case of introduction of extraordinary measures a very important role can be played by legal obligations addressing telecommunication companies. A multitude of orders and prohibitions concerning specific action in practice may raise some doubts. What is important - in the case of the said duties, many fields of legal institutions will apply. In the era of widespread terrorist threat, legal instruments aimed at telecommunications companies can play an important preventive and preservative role. The relevant services, in cooperation with telecommunication operators, may prevent many tragedies and take care of the security of the state in a more effective way. 